the combination of the ring current and corpuscular flux fields with the Earth's main field. Subsidiary hypotheses are involved, without present proof, to explain several complicated features of the phenomena observed.

Until recently most auroral and storm theories based on solar streams and clouds ignored the possible permanent presence of gas in interplanetary space and in the region around the Earth where the ring current and corpuscular flux current are believed to flow. The magnetic changes associated with these currents were supposed to be transmitted to the Earth's surface as if in vacuo. The radio phenomena of whistlers, elucidated by Eckersley and Storey, indicated the presence of electrons in at least part of the region. Parker for a time concluded that this would almost prevent the fields of the ring current and corpuscular flux current from affecting the Earth's surface field. Controversy with Hines finally led to agreement that this bar to transmission was misconceived. But the transmission will be by hydromagnetic waves rather than purely by electromagnetic waves. Chapman in rocent years has inferred that the Sun's coronal atmosphere extends up to and beyond the Earth, and that this interplanetary gas is very hot even up to the Earth's distance. He has further concluded that, if so, the Earth's atmosphere could be enormously more extensivo than formerly supposed. This would imply that the Van Allen belts lie relatively low in our atmosphere. But the atmospheric gas in their region, though far more dense than the energetic gas of the belts themselves, would probably bo too rare to have much influence on the development of magnetic storms and auroras.

\title{
OBITUARIES
}

\section{Prof. Charles Singer}

Dr. Charles Srnger, the eminent historian of medicine, science and technology, died at his beautiful home, 'Kilmarth', near Par, Cornwsll, on June 10, in his eighty-fourth year.

A son of the distinguished Hebrew scholer, the Rev. Simeon Singer, minister of the West End Synagogue, Charles Singer was born in Camberwell, on November 2, 1876, and was educated at the City of London School. At the age of seventeen he became a medical student at University College, London. But the delights of biology were at first too strong, and after a year he turned to the study of zoology and botany under Weldon and F. W. Oliver, respectively. After two years of these studies, he wes by a chance invited to enter for a scholarship at Magdalen College, Oxford. His success resulted in his spending three years at that College, studying zoology under Weldon (now transferred to Oxford) and under E. S. Goodrich, for both of whom he retained an immense admiration. In 1899 he graduated B.A. at Oxford, and then returned to London to continue his medical studies at St. Mary's Hospital, Paddington.

Singer qualified M.R.C.S., L.R.C.P. in 1903, and at once departed to Abyssinia as the medicel officer to a survey expedition to that country. The result was his first paper (1904) on some unusual clinicel conditions. Back in Britain, he filled various rosident posts to fit himself for a clinical career, and graduated B.M., B.Ch. at Oxford in 1905. He then had an extensive period in a post in the Government Hos. pital at Singapore. After his return to England, he became physician to the Dreadnought Hospital and concurrently registrar to the Cancer Hospital in Fulham Road. In the latter post he did much clinical research and laboratory research elone and in collaboration with S. B. Schryver. In 1913 he described a nematode worm in a gastric carcinoma in a rat. He discovered it in the same week in which Fibiger published the researches for which he received a Nobel Prize.

Charles Singer had entered the field of the history of medicine in 1911. $H_{\theta}$ took a prominent part in the early proceedings of the History Section of the Royal Society of Medicine, established in 1912. Osler was its first president, and just before the outbreak of the First World War he offered Singer a post at Oxford, the duties of which were to be mainly historical. Singer's tenure of this post was interrupted by the War, during which he served, mainly at Malta and Salonika, with the rank of captain in the R.A.M.C. But before he was commissioned early in the War he had time to establish, with the help of his wife, Dorothea Waley Singer, whom he had married in 1910, a History of Science Room in the Radcliffe Camera, which is still remembered.

After the War, Singer was invited in 1920 to lecture on the history of medicine at University College, London, and for a short time he continued to hold both the London and the Oxford posts. With his resignation from Oxford there began the most prolifie period of his life. In 1930 the University of London conferred on him the title of professor, and he became professor emeritus on his retirement in 1942. In 1930 and again in 1932 he acted as visiting professor at the University of California, Berkeley, where he lectured to enthusiastic audiences. In 1934 he removed his residonce to the house near Par, in Cornwall, which was to be his home during the remainder of his long life. Many friends from all over the world remember with pleasure and regret the hospitality so generously extended to them at 'Kilmarth'.

Until he was more than fifty, Singer's interests: lay mainly in the history of medicine. In that field he published in rapid sequence several works which opened new ground and led to further study by others. His "Early English Magic and Medicine", (1920) was probably the first serious study of AngloSaxon medicine since Cockayne. To the history of anatomy he contributed two important books on medieval anatomical texts (1924-25), and in the laster. year there appeared his "Evolution of Anatomy", the substance of his FitzPatrick Lectures. This work was virtually the only history of anatomy in English. The close of this book with Harvey indicated the limit of Singer's serious interest in the history of medicine. Apart from ephemeral writings, none of his original work on the history of medicine dealt with events after the Restoration. He was deeply interested in Greek and Roman medicine, in the medicine of the Dark Ages, and in the histiory of syphilis. His important paper on the herbal in 
antiquity was published in 1927. His early medical period closed in 1928 with the publication of his "Short History of Medicine".

Singer's interest in the history of science was at first confined largely to biology and the history of microscopy. The first volume of his "Studies in the History and Method of Science" (1917) contained papers by him which were medical rather than scientific; but the second volume (1921) contained his very important study of Greek biology, and also his paper on the invention of the first optical apparatus. Thereafter he published (1922) his useful little book on "Greek Biology and Greek Medicine". After that, occasional papers on biological and scientific subjects began to appear, and in 1931 he published-. as a result of his American lectures-his "Short History of Biology", one of his best books, which he afterwards revised twice.

After this, it was ten years before Singer published another important book. In the intervening period he had spent nearly a year in the United States, had removed to Cornwall, and had written many articles and reviews. He had also played a prominent part in the foundation of the Society for the Protection of Science and Learning, for he was deeply saddened by what happened to European scholars before the outbreak of the Second World War. He had also been reading widely in the literature of science, and the result was his "Short History of Science", published in 1941. This work was much read because it covered the whole field to 1900 within reasonable compass ; it introduced a new approach and was easily understood. Towards the end of the War he worked on the "Tabulae anatomicae sex" of Vesalius, and later he completed the philological aspects in collaboration with Prof. Chaim Rebin. This work wes published in 1946 as "A Prelude to Modern Science".

In the closing years of the War, Singer was asked by Mr. Derek Spence to write the history of the alum trade; Mr. Spence's well-known firm, dating beck to 1855 , contributed much to the later history of thet trade. For Singer this was a new departure, and he devoted several years of enthusiastic work to this effort. The result was the fine folio volume, "The Earliest Chemicel Industry", published in 1948.

Singer next turned to three medical projects which had long been in his mind. The first was the completion, in collaboration with his old friend, Prof. J. H. G. Gratton, of a definitive text of the Anglo. Saxon work known as the "Lacnunga". This work was published in 1952, as also was the second of these projects, a translation of the seventh book of the "Fabrica" of Vesalius.

The need for an authoritative work on the history of technology had long been understood by Singer, and after the publication of his work on the alum trade he devoted much time to the planning of a co-operative work on this subject. The drawing up of these detailed plans for five large volumes must be considered as one of Singer's finest pieces of work. It gave him scope for the use and display of his vast knowledge of men and books, and for the extensive correspondence in which he delighted. Although he had associated editors, chief of whom was the late Dr. E. J. Holmyard, Singer played the main part in the planning and editing of this work. The first volume was published in 1954 , and the fourth and fifth volumes in 1958. During its publication he completed and published his last original medical work, his annotated translation of "Galen on Anatomica, Procedures" (1956).
In 1922 Singer was awarded a D.Litt. at Oxford for his thesis on the manuscripts dealing with Si. Hildegard of Bingen. He already had the Oxford D.M. (1911), and in 1936 that University conferred on him the honorary degree of D.Sc. He became a Fellow of the Royal College of Physicians in 1917. Later in life he became a Fellow of University College, London, an Honorary Fellow of the Royal Society of Medicine, end an Honorary Fellow of his old college, Magdalen, at Oxford. He delivered the $\mathrm{J}_{\text {. }} \mathrm{T}$. Hobhouse Memorial Trust Lecture in 1951, and the Lloyd Roberts Lecture in 1954 . He was president of the History of Medicine Section of the Royal Society of Medicine during 1920-22, and first president of the British Society for the History of Science (194648). He was also president of two International Congresses held in London (History of Medicine, 1922 ; and History of Science, 1931). In 1947 he was president of the International Union for the History of Science. He was awarded the Osler Medal and the George Sarton Medal. In 1953 Singer wss the recipient of a large work containing historical essays written in his honour ("Science Medicine end History", 2 vols.; London, 1953).

Singer wes by inclination end treining a biologist, and to the end of his life he rather regretted that he had not taken up this subject as a profession. When the King's School at Canterbury was evacuated to the west of England early in the Second World War, he was induced to take over the teaching of practical biology. For this purpose he had a room in his house fitted out as 8 laboratory, and during most of the War he taught in it pupils attending that and another school. It gave him great satisfaction that he consistently obtained a very high standard of passes. In botany, Singer was especially interested in the suceculents, and in front of his desk there stood a thriving array of these plants.

Charles Singer will be remembered as much for the encouragement which he gave to others as for his own numerous and important contributions to hi: subjects. His large correspondence testified to the advice which he gave. But his inspiration and encouragemont flowed most, eesily in his conversation. Those who knew him well appreciated that, despite his learning, his humanity was perhaps the outstanding fecture of his character. He had a rich fund of humour, and he could talk simply is the unlearned about subjects which were by no means; simple. His studies in the local history and custom: of Cornwall were unpublished, and were probably known to very fow except his Cornish neighbours.

\section{E. AsHWORTH UNDERWOOD}

\section{Dr. Geoffrey Builder}

THE sudden death of Geoffrey Builder at the early age of fifty-four has deprived the University of sydney of an original and sympathetic teacher of physics and Australia of a scientist of international reputation. Born in Western Australia, he was educated at Guildford Grammar School, the Perth Technical College and the University of Western Australia. After graduating in 1928 he joined the Watheroo Magnetic Observatory of the Carnegie Institution of Washington and was responsible for developing a radio technique for the rapid transmission of geophysical data to Washington.

In 1931 Builder commenced work under me at King's College, London, on the exploration of the 